\title{
Widespread Expression of Netrin-1 by Neurons and Oligodendrocytes in the Adult Mammalian Spinal Cord
}

\author{
Colleen Manitt, ${ }^{1}$ Michael A. Colicos, ${ }^{1}$ Katherine M. Thompson, ${ }^{1}$ Etienne Rousselle, ${ }^{1}$ Alan C. Peterson, ${ }^{2}$ and \\ Timothy E. Kennedy ${ }^{1}$ \\ ${ }^{1}$ Centre for Neuronal Survival, Montreal Neurological Institute, and 2Molecular Oncology Group, Royal Victoria Hospital, \\ McGill University, Montreal, Quebec, Canada, H3A 2B4
}

\begin{abstract}
Netrins are a family of secreted proteins that function as chemotropic axon guidance cues during neural development. Here we demonstrate that netrin- 1 continues to be expressed in the adult rat spinal cord at a level similar to that in the embryonic CNS. In contrast, netrin-3, which is also expressed in the embryonic spinal cord, was not detected in the adult. In situ hybridization analysis demonstrated that cells in the white matter and the gray matter of the adult spinal cord express netrin- 1 . Colocalization studies using the neuronal marker NeuN revealed that netrin- 1 is expressed by multiple classes of spinal interneurons and motoneurons. Markers identifying glial cell types indicated that netrin-1 is expressed by most, if not all, oligodendrocytes but not by astrocytes. During neural development, netrin-1 has been proposed to function as a diffusible long-range cue for growing axons. We show that in the adult
\end{abstract}

Netrin-1 is a secreted protein produced by axonal targets during neural development. Appropriate expression of netrin- 1 in vivo is essential for certain types of axons, such as those of embryonic spinal commissural neurons, to grow toward a netrin-expressing target (Serafini et al., 1996). Studies examining netrin function in vitro have demonstrated that netrin- 1 is diff usible and can orient axon growth at a distance from the source of netrin protein. These findings suggest that netrin- 1 acts as a long-range chemotropic axon guidance cue during development (Kennedy et al., 1994; Colamarino and Tessier-Lavigne, 1995a; Shirasaki et al., 1996; Varela-Echavarria et al., 1997). Netrins are versatile cues, attracting the growth cones of some axons and repelling others. That netrin might be a bifunctional axon guidance cue was first suggested by the phenotype of Caenorhabditis elegans mutants lacking UNC-6, the C. elegans homolog of netrin. In unc-6 mutants, the trajectories of axons growing toward or away from cells expressing unc-6 were disrupted (Hedgecock et al., 1990; Ishii et al., 1992). Two other mutations, unc-40 and unc-5, produce related axon guidance phenotypes. Both encode transmembrane

\footnotetext{
Received April 28, 2000; revised Feb. 21, 2001; accepted March 6, 2001.

This work was supported by the Paralyzed Veterans of America Spinal Cord Research Foundation, the Multiple Sclerosis Society of Canada, and the Medical Research Council (MRC) of Canada. T.E.K. is a scholar of the MRC. We thank Adriana Di Polo, Dena Howland, Stephen Morris, Laurence Simard-Emond, Simon Moore, Jean-Francois Bouchard, and Andrew Jarjour for critically reading this manuscript and Elena Malitskaya for technical assistance.

GenBank Accession Numbers: rat netrin-1, AY028417; rat netrin-3, AY028418.

Correspondence should be addressed to Dr. Timothy E. Kennedy, Centre for Neuronal Survival, Montreal Neurological Institute, McGill University, 3801 University Street, Montreal, Quebec, Canada, H3A 2B4. E-mail: tkenne5@po-box. mcgill.ca.

Copyright (C) 2001 Society for Neuroscience $\quad 0270-6474 / 01 / 213911-12 \$ 15.00 / 0$
}

spinal cord the majority of netrin-1 protein is not freely soluble but is associated with membranes or the extracellular matrix. Fractionation of adult spinal cord white matter demonstrated that netrin-1 was absent from fractions enriched for compact myelin but was enriched in fractions containing periaxonal myelin and axolemma, indicating that netrin-1 protein may be localized to the periaxonal space. These findings suggest that in addition to its role as a long-range guidance cue for developing axons, netrin may have a short-range function associated with the cell surface that contributes to the maintenance of appropriate neuronal and axon-oligodendroglial interactions in the mature nervous system.

Key words: netrin-1; netrin-3; adult spinal cord; oligodendrocyte; regeneration; multiple sclerosis

members of the Ig superfamily, and both are expressed by neurons as they extend axons (Leung-Hagesteijn et al., 1992; Chan et al., 1996). UNC-40 is homologous to mammalian deleted in colorectal cancer (DCC) (Chan et al., 1996; Keino-Masu et al., 1996), and three mammalian UNC-5 homologs have now been identified (Ackerman et al., 1997; Leonardo et al., 1997). Both genetic and biochemical evidence suggest that DCC and UNC-5 family members interact to form a netrin receptor complex mediating the response to netrin-1 (Hedgecock et al., 1990; McIntire et al., 1992; Colavita and Culotti, 1998; Hong et al., 1999).

In addition to their function as long-range axon guidance cues, evidence derived from genetic analysis in Drosophila melanogaster supports a short-range role for netrin protein expressed by muscle cells at some developing nerve $\rightarrow$ muscle synapses (Winberg et al., 1998). Like the long-range chemoattractant function of netrin-1, this short-range action is also dependent on neuronal expression of frazzled, the D. melanogaster homolog of DCC. The mechanisms underlying the similarities and differences between the short-range and long-range functions of netrins are not clear; however, these results raised the intriguing possibility that netrins mediate short-range cell-cell interactions (for review, see Kennedy, 2000).

Here we address the expression and distribution of netrin- 1 in the adult mammalian CNS. We show that netrin-1 is constitutively expressed by neurons and oligodendrocytes in the adult rat spinal cord and that the majority of the netrin-1 protein present is not freely soluble but associated with membranes or extracellular matrix (ECM). Furthermore, fractionation of adult spinal cord white matter indicates that netrin-1 is enriched in periaxonal myelin, suggesting that netrin-1 protein is concentrated at the 
interface between axons and oligodendrocytes. These findings suggest that, like the role of netrin at nerve $\rightarrow$ muscle synapses in D. melanogaster, netrin-1 may have a short-range function that mediates neuronal and axon-oligodendroglial interactions in the adult CNS.

\section{MATERIALS AND METHODS}

Animals. Adult male Sprague Dawley rats (250-400 gm) were obtained from Charles River Canada. A transgenic mouse line in which a lacZ reporter gene replaces exon 1 of the myelin basic protein $(M B P)$ gene was used to mark the oligodendrocyte lineage (Bachnou et al., 1997). All procedures with animals were performed in accordance with the Canadian Council on Animal Care guidelines for the use of animals in research.

Cloning rat netrin-1 and rat netrin-3. Total RNA was isolated from adult rat spinal cord or embryonic day 18 (E18) rat brain using Trizol (Life Technologies, Gaithersburg, $\mathrm{MD})$ and $\operatorname{poly}\left(\mathrm{A}^{+}\right)$RNA purified using the Oligotex mRNA mini kit (Qiagen). Rat netrin-1 and rat netrin-3 cDNAs were amplified from randomly primed cDNA and cloned using primers derived from nucleotide sequences conserved between human and mouse netrins (Serafini et al., 1996; van Raay et al., 1997; Meyerhardt et al., 1999; Wang et al., 1999). Multiple cDNAs derived from at least three independent amplifications of each clone were generated using the $\mathrm{P} f u$ high-fidelity thermostable polymerase (Stratagene, La Jolla, CA) and were sequenced (Bio S\&T) to identify potential errors that might have been introduced during amplification. No sequence discrepancies between independent clones were found. For rat netrin-1 the primer sequences used were as follows: GCGTGGTGAGCGAGCGTGGTGAAG and CTAGGCCTTCTTGCACTTGCCCTTCT; and for rat netrin-3 the primer sequences used were the following: TCTGCCGACCCCTGCTATGATGA and GCGGCGGCCAGACAGTCGGTAGAG. Primers were annealed at $68^{\circ} \mathrm{C}$, and 30 cycles of amplification were performed. Sequence alignments were performed using Align analysis software (Dnastar). Additional sequence for rat netrin-1 was obtained from ESTs AW251519, AA859374, and AI502501, and for rat netrin-3 from EST AI072413. EST cDNAs were obtained from Research Genetics.

Antibodies, immunohistochemistry, and Western blot analysis. Netrin immunoreactivity was detected using rabbit polyclonal antibodies PN2 and PN3. PN2 was raised against an 18 amino acid peptide (\#11760, RFNMELYKLSGRKSGGVC) present in rat netrin-1. This sequence is $100 \%$ conserved in netrin- 1 of human, mouse, chick, and frog (Serafini et al., 1994, 1996; de la Torre et al., 1997; Meyerhardt et al., 1999). PN3 was raised against domains $\mathrm{V}$ and $\mathrm{VI}$ of chick netrin-1 that have $>90 \%$ amino acid identity between the species listed above. To prevent nonspecific binding, antibodies were affinity purified and preadsorbed against acetone-extracted chicken liver protein. No netrin family members have been detected in extracts of chicken liver (Kennedy et al., 1994).

LacZ expression was visualized using a mouse monoclonal antibody against $\beta$-galactosidase ( $\beta$-gal; dilution, 1:1000; Promega, Madison, WI). A mouse monoclonal antibody against the oligodendrocyte marker $2^{\prime}, 3^{\prime}$ cyclic nucleotide $3^{\prime}$-phosphodiesterase (CNP) was used at a dilution of 1:1000 (Sternberger Monoclonals), and a mouse monoclonal antibody against the astrocyte marker glial fibrillary acidic protein (GFAP) was used at a dilution of 1:500 (Sigma). A mouse monoclonal antibody against the neuronal marker NeuN was used at a dilution of 1:25 (gift from Dr. Richard Mullen).

For immunohistochemical analyses, adult rats and mice were anesthetized with sodium pentobarbital (Somnotol; $65 \mathrm{mg} / \mathrm{kg}$, i.p.; MTC Pharmaceuticals) and perfused transcardially with PBS containing heparin (1 U/ml; Fisher Scientific), followed by $4 \%$ paraformaldehyde (Fisher Scientific) and $15 \%$ picric acid (Sigma) in PBS, pH 8.5, at $37^{\circ} \mathrm{C}$. Spinal cords were dissected and post-fixed in the same fixative at $4^{\circ} \mathrm{C}$ overnight and equilibrated in $30 \%$ sucrose, $4 \%$ paraformaldehyde, and $15 \%$ picric acid at $\mathrm{pH}$ 8.5. Spinal cords were then embedded in optimal cutting temperature compound (Tissue Tek; Sakura Finetek), and $25 \mu \mathrm{m}$ sections were cut using a cryostat. Free-floating sections were rinsed in PBS for $5 \mathrm{~min}$, and endogenous peroxidase activity was quenched by incubation in $70 \%$ methanol and $1 \% \mathrm{H}_{2} \mathrm{O}_{2}$ (Fisher Scientific). Netrin antigenicity was enhanced by gradually heating the sections to $95^{\circ} \mathrm{C}$ in a 10 -fold dilution of PBS in water. Sections were then returned to PBS. Tissue sections were incubated for $1 \mathrm{hr}$ at room temperature in blocking solution: $2 \%$ bovine serum albumin (ICN Biomedicals, Cleveland, $\mathrm{OH}$ ), $2 \%$ heat-inactivated normal goat serum (Life Technologies), and 0.2\% Triton X-100 (Fisher Scientific) in PBS. Sections were incubated with netrin primary antibodies in blocking solution overnight at $4^{\circ} \mathrm{C}$, followed by goat anti-rabbit peroxidase-conjugated secondary antibody (1:400 dilution; Life Technologies). Immunoreactivity was visualized using a diaminobenzidene (DAB) detection kit with nickel chloride enhancement (Vector Laboratories). For immunofluorescence analysis, primary antibodies were visualized using secondary antibodies coupled to indocarbocyanine (Cy3) or FITC (Jackson ImmunoResearch, West Grove, PA). Autofluorescence was reduced using $0.1 \%$ sodium borohydride solution (Fisher Scientific) as described previously (Clancy and Cauller, 1998). Slides were mounted using Elvanol (DuPont NEN, Wilmington, DE) with 2.5\% 1,4diazabicyclo[2,2,2]octane (Sigma).

For Western blots, netrin antibodies PN2 and PN3 were used at concentrations of 1.0 and $0.7 \mu \mathrm{g} / \mathrm{ml}$, respectively. We used the following rabbit polyclonal antibodies raised against the endoplasmic reticulum (ER) integral membrane protein calnexin (gift of Dr. John M. Bergeron) at a dilution of 1:2000, the ER resident protein BiP (gift of Dr. Linda Hendershot) at a dilution of 1:1000 (Hendershot et al., 1995), the 160 $\mathrm{kDa}$ membrane sialoglycoprotein (MG-160) of the medial cisternae of the Golgi apparatus (gift of Dr. N. K. Gonatas) at a dilution of 1:1000 (Croul et al., 1990), and the plasma membrane protein trk-B (gift of Dr. Louis Reichardt) at a dilution of 1:2000. The following mouse monoclonal antibodies were used: anti-CNP at a dilution of 1:100,000 (Sternberger Monoclonals), anti-MBP at a dilution of 1:500 (Chemicon International, Temecula, CA), anti-neurofilament-145 (NFM) at a dilution of 1:50,000 (Chemicon International), and anti-myelin-associated glycoprotein (MAG) at a dilution of 1:100,000 (gift of Dr. Peter E. Braun).

Protein homogenates were separated using 10\% PAGE and transferred to immobilon (Millipore, Bedford, MA) or nitrocellulose membrane (Amersham Pharmacia Biotech). Membranes were incubated in $5 \%$ milk powder, $1 \%$ glycine (Fisher Scientific), $0.1 \%$ Tween 20 (Fisher Scientific), $3 \%$ heat-inactivated normal goat serum (Life Technologies), and $0.1 \%$ SDS (Fisher Scientific) for $1 \mathrm{hr}$ at room temperature, followed by incubation with primary antibodies overnight in blocking solution at $4^{\circ} \mathrm{C}$. Immunoreactivity was visualized using peroxidase-conjugated donkey anti-rabbit or donkey anti-mouse secondary antibodies (1:4000; Jackson ImmunoResearch) and the Chemiluminescence Reagent Plus protein detection kit (NEN). Densitometry and quantification of the relative level of netrin protein were performed on scanned images of immunoblots (Epson ES 1200C) using NIH Image software (National Institutes of Health).

In situ hybridization. Sense and antisense cRNA probe pairs corresponding to 933 bases of rat netrin-1, nucleotides $882-1815$, were used. A shorter antisense transcript corresponding to nucleotides 852-1046 in rat netrin-1 produced a pattern of hybridization identical to that of the antisense probe described above (data not shown). For probe synthesis, cDNA templates were isolated from agarose gels, and cRNA transcription was performed using polymerases T7 (New England Biolabs, Beverly, MA) or T3 (Promega) and digoxigenin (DIG) RNA labeling mix (Roche Products).

After transcardial perfusion with $150 \mathrm{ml}$ of PBS, $\mathrm{pH} 7.5$, and heparin $(1 \mathrm{U} / \mathrm{ml})$ at $37^{\circ} \mathrm{C}$, spinal cords were rapidly dissected and frozen by immersion in 2-methylbutane (Fisher Scientific) chilled in liquid nitrogen. Five micrometer cryostat sections were mounted onto slides (Superfrost Plus; Fisher Scientific) and fixed by immersion in $4 \%$ paraformaldehyde and $15 \%$ picric acid, $\mathrm{pH} 8.5$, in $\mathrm{PBS}$ for $45 \mathrm{~min}$ at room temperature. Sections were then rinsed in $2 \times \mathrm{SSC}$, equilibrated for $5 \mathrm{~min}$ in $10 \mathrm{~mm}$ triethanolamine (Fisher Scientific), and incubated in $0.25 \%$ acetic anhydride (Sigma) in $10 \mathrm{~mm}$ triethanolamine for $10 \mathrm{~min}$ at room temperature. In situ hybridization was performed as described previously (Braissant and Wahli, 1998) using DIG-labeled probes. Sections were transferred to prehybridization solution $(50 \%$ formamide, $5 \times$ SSC, $5 \times$ Denhardt's, $1 \%$ SDS, and $40 \mu \mathrm{g} / \mathrm{ml}$ single-stranded salmon sperm DNA) for $20 \mathrm{~min}$ at room temperature. Hybridization was performed in $100 \mu \mathrm{l}$ of solution containing $200 \mathrm{ng}$ of probe in $50 \%$ formamide, $5 \times$ SSC, and $40 \mu \mathrm{g} / \mathrm{ml}$ single-stranded salmon sperm DNA, overnight at $57^{\circ} \mathrm{C}$. Sections were then washed in $2 \times \mathrm{SSC}$ at room temperature followed by a wash in $2 \times \mathrm{SSC}$ for $1 \mathrm{hr}$ at $65^{\circ} \mathrm{C}$. Hybridization was detected using a peroxidase-coupled antibody against DIG (Roche Products), amplified using the TSA-Indirect (ISH) Tyramide Signal Amplification kit (NEN), and visualized with peroxidase/DAB detection (Vector Laboratories).

Northern blot analysis. Poly $\left(\mathrm{A}^{+}\right)$RNA was isolated from spinal cord, the cervical through thoracic region. $\left[\alpha-\mathrm{P}^{32}\right] \mathrm{dCTP}$ was incorporated into a 462 base pair rat netrin- 1 cDNA probe by PCR ( $5^{\prime}$ primer, GCGT- 
GCGCGACCGAGACGACAGT; 3' primer, TGGGGGAGCGGCTCTGCTGGTAGC), and the probe was purified using a NucTrap column (Stratagene). Two micrograms of poly $\left(\mathrm{A}^{+}\right)$RNA were separated on a $1 \%$ formaldehyde-agarose gel, capillary blotted to Hybond $\mathrm{N}$ membrane (Amersham Pharmacia Biotech), and probed using standard methods (Ausubel et al., 1990).

Subcellular fractionation. Subcellular fractionation of protein derived from total adult rat spinal cords was performed essentially as described for embryonic chick brain (Serafini et al., 1994). Spinal cords were homogenized in a glass-glass Potter-Elvehjem homogenizer on ice using $5 \mathrm{ml}$ of homogenization buffer [320 mM sucrose, $10 \mathrm{mM}$ HEPES, $\mathrm{pH} 7.5$, and protease inhibitors ( $1 \mathrm{mM}$ EDTA, $2 \mu \mathrm{g} / \mathrm{ml}$ leupeptin, $2 \mu \mathrm{g} / \mathrm{ml}$ aprotinin, $1 \mu \mathrm{g} / \mathrm{ml}$ pepstatin, and $2 \mathrm{~mm}$ PMSF)]. Homogenization consisted of two sets of 15 strokes with a 5 min pause between the sets. Crude homogenates were centrifuged at $1000 \times \mathrm{g}$ at $4^{\circ} \mathrm{C}$ for $10 \mathrm{~min}$ (low-speed spin). The low-speed pellet (LSP) and an aliquot of the low-speed supernatant (LSS) were stored at $-80^{\circ} \mathrm{C}$. The remainder of the LSS was centrifuged at $10,000 \times \mathrm{g}$ at $4^{\circ} \mathrm{C}$ for $10 \mathrm{~min}$ (medium-speed spin). The medium-speed supernatant 1 (MSS1) was stored on ice, and the first medium-speed pellet (MSP1) was resuspended in resuspension buffer (RB; $10 \mathrm{~mm}$ HEPES, $\mathrm{pH} 7.5$, and protease inhibitors) and centrifuged again at $10,000 \times \mathrm{g}$ at $4^{\circ} \mathrm{C}$ for $10 \mathrm{~min}$. The final MSP was resuspended in $\mathrm{RB}$ and stored at $-80^{\circ} \mathrm{C}$; the second medium-speed supernatant (MSS2) was pooled with the first (MSS1), and an aliquot of the medium-speed supernatant (MSS) was stored at $-80^{\circ} \mathrm{C}$. The remainder of the pooled MSS was centrifuged at $230,000 \times \mathrm{g}$ at $4^{\circ} \mathrm{C}$ for $35 \mathrm{~min}$ (high-speed spin). The high-speed supernatant (HSS) containing soluble protein was stored at $-80^{\circ} \mathrm{C}$. The high-speed pellet (HSP) was resuspended in high-salt extraction buffer (HSEB; $1.5 \mathrm{M} \mathrm{NaCl}, 10 \mathrm{~mm}$ HEPES, $\mathrm{pH} 7.5$, and protease inhibitors); an aliquot was stored at $-80^{\circ} \mathrm{C}$, and the remainder was incubated for $1 \mathrm{hr}$ rotating at $4^{\circ} \mathrm{C}$. High-salt extract was then centrif uged at $100,000 \times \mathrm{g}$ for $2 \mathrm{hr}$ yielding the high-salt extract pellet (HSEP) and high-salt extract supernatant (HSES).

Myelin fractionation. Myelin fractionation was performed on the basis of a protocol described by Detskey et al. (1988) as modified by Sapirstein et al. (1992). Spinal cords were dissected from 10 adult rats (350-400 gm). All homogenizations were performed using a Dounce homogenizer (Fisher Scientific). The initial homogenization consisted of six strokes with a loose pestle, followed by four strokes with a tight pestle, in ice-cold buffer containing $0.9 \mathrm{~m}$ sucrose, $150 \mathrm{~mm} \mathrm{NaCl}$, and $10 \mathrm{~mm}$ HEPES, $\mathrm{pH}$ 7.5. The volume was brought to $210 \mathrm{ml}$, and protease inhibitors were added ( $5 \mathrm{~mm}$ EDTA, $2 \mu \mathrm{g} / \mathrm{ml}$ leupeptin, $2 \mu \mathrm{g} / \mathrm{ml}$ aprotinin, $1 \mu \mathrm{g} / \mathrm{ml}$ pepstatin, and $2 \mathrm{~mm}$ PMSF). Homogenates (fraction 1) were then centrifuged at $82,500 \times g$ for $25 \mathrm{~min}$ at $4^{\circ} \mathrm{C}$. The crude myelin fraction was isolated as a pellet floating at the top of the sucrose solution (fraction 2). The crude gray matter fraction pelleted at the bottom of the tube (fraction 3). Crude myelin pellets were then rehomogenized with six strokes of a loose pestle, followed by four strokes with a tight pestle, in $210 \mathrm{ml}$ of ice-cold $0.85 \mathrm{M}$ sucrose containing protease inhibitors. The homogenate was then spun at $82,500 \times g$ for $25 \mathrm{~min}$ at $4^{\circ} \mathrm{C}$. The resulting floating pellets were rehomogenized in osmotic shock buffer containing 10 mM HEPES, pH 7.4, 5 mM EDTA, and protease inhibitors to separate myelin from crude periaxolemma. Homogenates were gently rotated for $1.5 \mathrm{hr}$ at $4^{\circ} \mathrm{C}$, layered onto a discontinuous sucrose gradient composed of $15,24,28,32$, and $37 \%$ sucrose, and then centrifuged at $82,500 \times g$ for $13 \mathrm{hr}$ at $4^{\circ} \mathrm{C}$. The myelin fraction (fraction 4) was collected from the $15-24 \%$ interface, and the crude periaxolemmal fraction (fraction 5) was from the $28-32 \%$ interface. To remove residual nonmyelin microsomal contaminants, the myelin fraction was osmotic shocked twice in $\mathrm{ddH}_{2} \mathrm{O}$ and sedimented at $12,000 \times g$. After the second sedimentation the pellet was resuspended in $\mathrm{ddH}_{2} \mathrm{O}$, layered over a $0.75 \mathrm{~m}$ sucrose solution, and centrifuged at $75,000 \times g$ for $1.5 \mathrm{hr}$ at $4^{\circ} \mathrm{C}$. The purified myelin fraction (fraction 6) was collected from the $\mathrm{ddH}_{2} \mathrm{O}-0.75 \mathrm{M}$ interface. The crude periaxolemmal fraction was lysed for $30 \mathrm{~min}$ in $5 \mathrm{~mm}$ Tris- $\mathrm{HCl}, \mathrm{pH} 8.3$, $5 \mathrm{~mm}$ EDTA, and protease inhibitors. After lysis, one-quarter of the volume of $40 \%$ sucrose was added and then layered over a sucrose gradient composed of $0.65,0.8$, and $1.0 \mathrm{M}$ sucrose and centrifuged at $75,000 \times g$ for $1.5 \mathrm{hr}$. The periaxonal myelin fraction (fraction 7) was collected from the $0.65-0.8 \mathrm{M}$ interface, and the axolemma fraction (fraction 8) was collected from the $0.8-1.0 \mathrm{M}$ interface. Protein content was quantified using the BCA protein assay kit (Pierce, Rockford, IL), and the fractions were assayed using PAGE and Western blot analysis.

\section{RESULTS \\ Netrin-1 is expressed in the adult mammalian spinal cord}

Identical $1.6 \mathrm{~kb}$ rat netrin-1 cDNAs were amplified from adult rat spinal cord and brain poly $\left(\mathrm{A}^{+}\right)$RNA. Additional 5' sequence was obtained from ESTs AW251519 and AI502501 (Bonaldo et al., 1996). The sequence obtained encodes a full-length open-reading frame $98 \%$ identical to the predicted amino acid sequence of mouse netrin-1 (Serafini et al., 1996) but only 52\% like that of mouse netrin-3 (Wang et al., 1999). A previously identified rat cDNA sequence [163 nucleotides (Livesey and Hunt, 1997)] homologous to netrin-1 was contained within this sequence. We were unable to amplify a rat netrin-3 from adult rat spinal cord, but we were able to amplify a rat netrin-3 cDNA from E18 rat brain poly $\left(\mathrm{A}^{+}\right)$RNA. Additional 5' sequence of rat netrin-3, including the translation start site, was obtained from EST AI072413 (Bonaldo et al., 1996). The sequence of amino acids encoded by the 1030 base pair cDNA is $>96 \%$ identical to the predicted amino acid sequence of mouse netrin-3 (Wang et al., 1999).

Northern blot analysis of poly $\left(\mathrm{A}^{+}\right)$RNA derived from E14 rat brain and adult rat spinal cord revealed a single $\sim 6 \mathrm{~kb}$ mRNA corresponding to netrin-1 (Fig. 1B). The amount of mRNA detected indicates that netrin-1 is expressed at similar levels in the adult and embryonic CNS. In agreement with our inability to amplify a rat netrin-3 cDNA from adult spinal cord mRNA, Northern blot analysis of rat netrin-3 expression in E14 brain and adult spinal cord mRNA produced a detectable signal only in the E14 sample (Fig. 1B). We conclude that members of the netrin family are differentially expressed in the embryonic and adult CNS with netrin-1 expressed at readily detectable levels in the adult.

To characterize the expression of netrin protein we performed Western blot analysis of adult spinal cord homogenates using affinity-purified polyclonal antibodies raised against two different netrin-1 antigens. Antibody PN2 was raised against a peptide epitope conserved in all mammalian orthologs of netrin-1 identified to date (Serafini et al., 1996; Meyerhardt et al., 1999). However, two conservative amino acid substitutions are present in the corresponding 19 amino acid sequence in human, rat, and mouse orthologs of netrin-3 (van Raay et al., 1997; Wang et al., 1999). Antibody PN3 was raised against purified recombinant protein corresponding to domains V and VI of chick netrin-1, an $\sim 430$ amino acid sequence highly conserved in all identified vertebrate netrin-1 orthologs. Western blot analysis demonstrated that in addition to netrin-1, both PN2 and PN3 bind recombinant mouse netrin-3 (data not shown). Analysis of adult rat spinal cord homogenates using antibodies PN2 and PN3 revealed the presence of an $\sim 75 \mathrm{kDa}$ band consistent with the molecular weight of netrin-1 (Fig. $1 B$ ). In addition, preadsorption of PN2 or PN3 with a molar excess of recombinant netrin-1 protein abolished all staining on Western blots or tissue sections (data not shown). Because of the absence of detectable netrin-3 expression in the adult spinal cord, the high level of netrin-1 expression, and the molecular weight of the immunoreactive band, we conclude that immunoreactivity detected by antibodies PN2 and PN3 in homogenates of adult spinal cord corresponds to netrin-1.

Recently, two additional members of the netrin family have been identified in mammals: netrin-4 (Koch et al., 2000; Yin et al., 2000) and netrin-G1 (Nakashiba et al., 2000). Netrin-4 is more closely related to the $\beta$ chain of laminin than it is to netrin- 1 and 
Figure 1. Distribution of netrin-1-expressing cells in adult rat spinal cord. $A$, Illustration of a hemisection of an adult rat spinal cord [adapted from Paxinos (1995)] is shown. The boxes correspond to the regions displayed in the micrographs of dorsal spinal cord $(C$, top box in $A)$ and ventral spinal cord $(D$, bottom box in $A)$. $B$, Northern blot analysis of E14 rat brain and adult rat spinal cord poly $\left(\mathrm{A}^{+}\right)$ RNA ( $2 \mu \mathrm{g}$ of RNA) identified a single $\sim 6 \mathrm{~kb}$ mRNA transcript encoding netrin-1, and for netrin-3 identified a major transcript at $\sim 9 \mathrm{~kb}$ and several minor transcripts only in the E14 brain. Netrin-3 is not expressed at detectable levels in the adult spinal cord. RNA size standards correspond to $9.49,7.46,4.40,2.37,1.35$, and $0.24 \mathrm{~kb}$ (Bio-Rad, Hercules, CA). Western blot analyses of protein present in a high-salt extract of the membrane fraction of adult rat spinal cord homogenate using antibodies PN2 or PN3 are shown. Both antibodies reveal an $\sim 75 \mathrm{kDa}$ immunoreactive band, consistent with the molecular weight of netrin-1. The additional minor lower-molecular weight immunoreactive bands may be proteolytic fragments of full-length netrin protein. Protein size standards correspond to $116,97.4,66.2,45$, and $31 \mathrm{kDa}$ (Bio-Rad). $C-G$, In situ hybridization analysis identified netrin-1-expressing cells in all laminas and the white matter of dorsal $(C)$ and ventral $(D)$ hemisections of C5 spinal cord. $E$ illustrates the morphology of netrin-1-expressing cells in lamina IV of the dorsal horn. Hybridization was detected in the cytoplasm and the proximal portion of neurites. Large neurons in the ventral horn with the morphological characteristics of motoneurons express netrin-1 $(D, F)$. Netrin-1-positive cells were also detected throughout the white matter $(C, D)$. $G$ illustrates the morphology of netrin-1-positive cells located in ventral C5 white matter. Like the neurons in $E$ and $F$, positive hybridization was detected in the cytoplasm and proximal processes of these glial cells. The small inset in $C$ illustrates the absence of hybridization using the corresponding sense cRNA probe. $C-G$, Differential interference contrast (DIC) optics, digoxigenin-labeled probe visualized with a POD-conjugated secondary antibody against digoxigenin and the diaminobenzidine substrate, is shown. Objective magnification: $C, D, 10 \times ; E, F, 40 \times ; G, 100 \times$. Scale bars: $C, D, 150 \mu \mathrm{m} ; E, F, 50 \mu \mathrm{m} ; G, 25 \mu \mathrm{m}$. GAPDH, Glyceraldehyde-3-phosphate dehydrogenase.
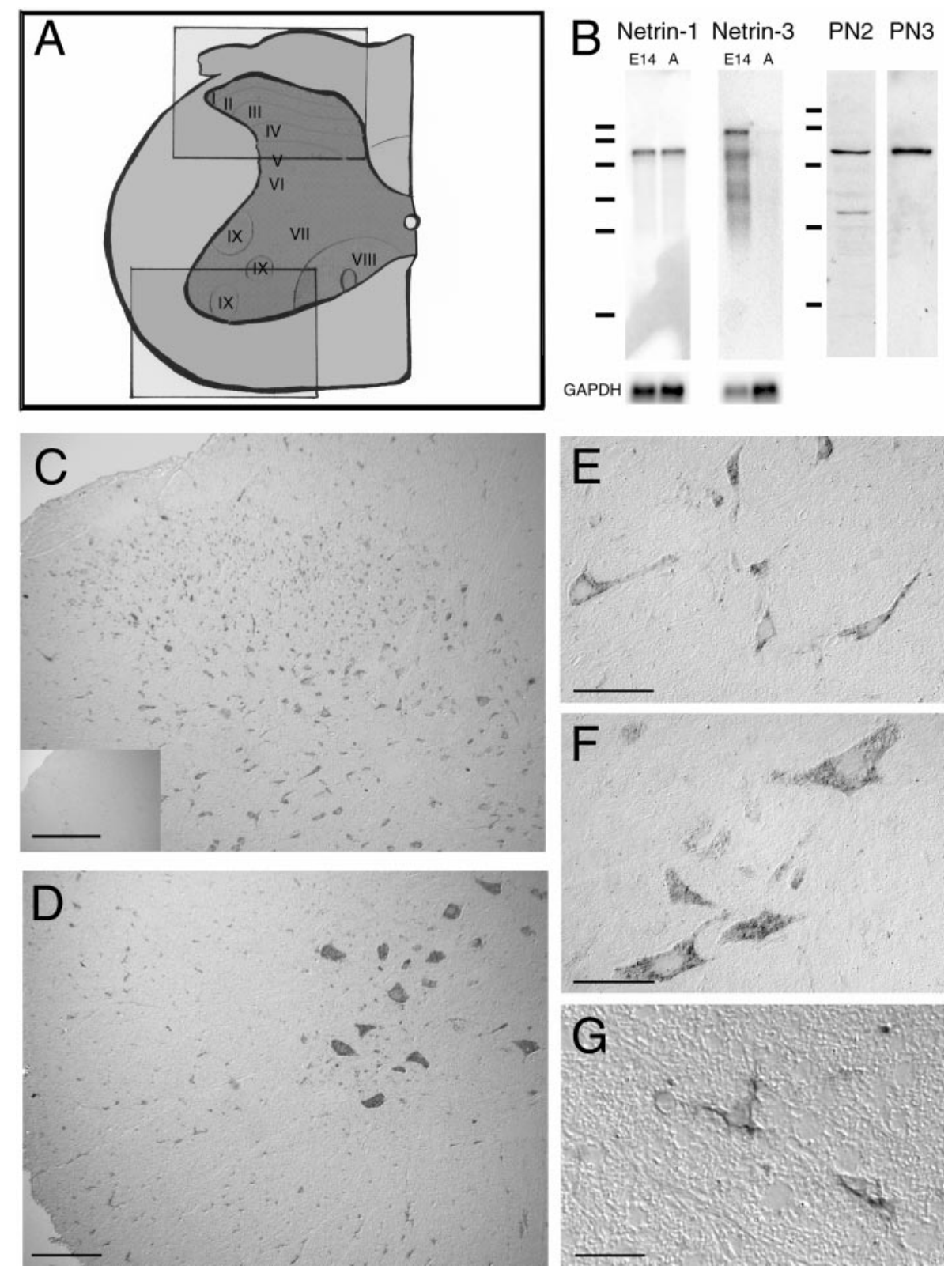

netrin-3, which are more closely related to the $\gamma$ chain of laminin. In mouse netrin-4, 7 of 18 amino acids are conserved in the sequence used to generate antibody PN2. This sequence is absent from mouse netrin-G1. The poor conservation of this epitope indicates that it is unlikely that antibody $\mathrm{PN} 2$ recognizes these netrins.

\section{Neurons and oligodendroglia express netrin-1 in adult spinal cord}

To identify the cell types that express netrin-1 in the adult rat spinal cord, the distribution of netrin-1 mRNA was investigated using in situ hybridization analysis. An antisense netrin-1 riboprobe (933 nucleotides) detected positively hybridizing cells in all laminas of the gray matter and throughout the white matter (Fig. $1 C-G)$. A second netrin-1 antisense riboprobe (196 nucleotides) detected an identical pattern of hybridization (data not shown). Corresponding sense probes produced no signal (Fig. 1C, inset). The morphology and distribution of many positive cells suggested that they were neurons (Fig. $1 E, F$ ); however, the presence of netrin-1-expressing cells in the white matter indicated that certain glia may also constitutively express netrin-1 (Fig. 1G).

The distribution of netrin protein in the adult spinal cord was assessed using the affinity-purified antibody PN2. Netrinimmunoreactive cells were present in the white matter and all laminas of the spinal cord (Fig. 2). These results are consistent with the distribution of netrin-1-expressing cells detected using in situ hybridization (Fig. 1). Particularly high levels of immunoreactivity were found in the dorsal horn. Strongly labeled cells with the morphological characteristics of spinal interneurons were present in the most superficial laminas (Fig. 2A,C) and in the neck of the dorsal horn (Fig. $2 A, D$ ). In addition to cell body staining, significant immunoreactivity was also detected in the neuropil. Much of this staining was fibrous, suggesting an association between netrin protein and neurites (Fig. $2 A, C, D$ ). Although present throughout the gray matter of the spinal cord, this pattern of staining was particularly clear in the lateral spinal nucleus and lateral cervical nucleus. These nuclei contained a 

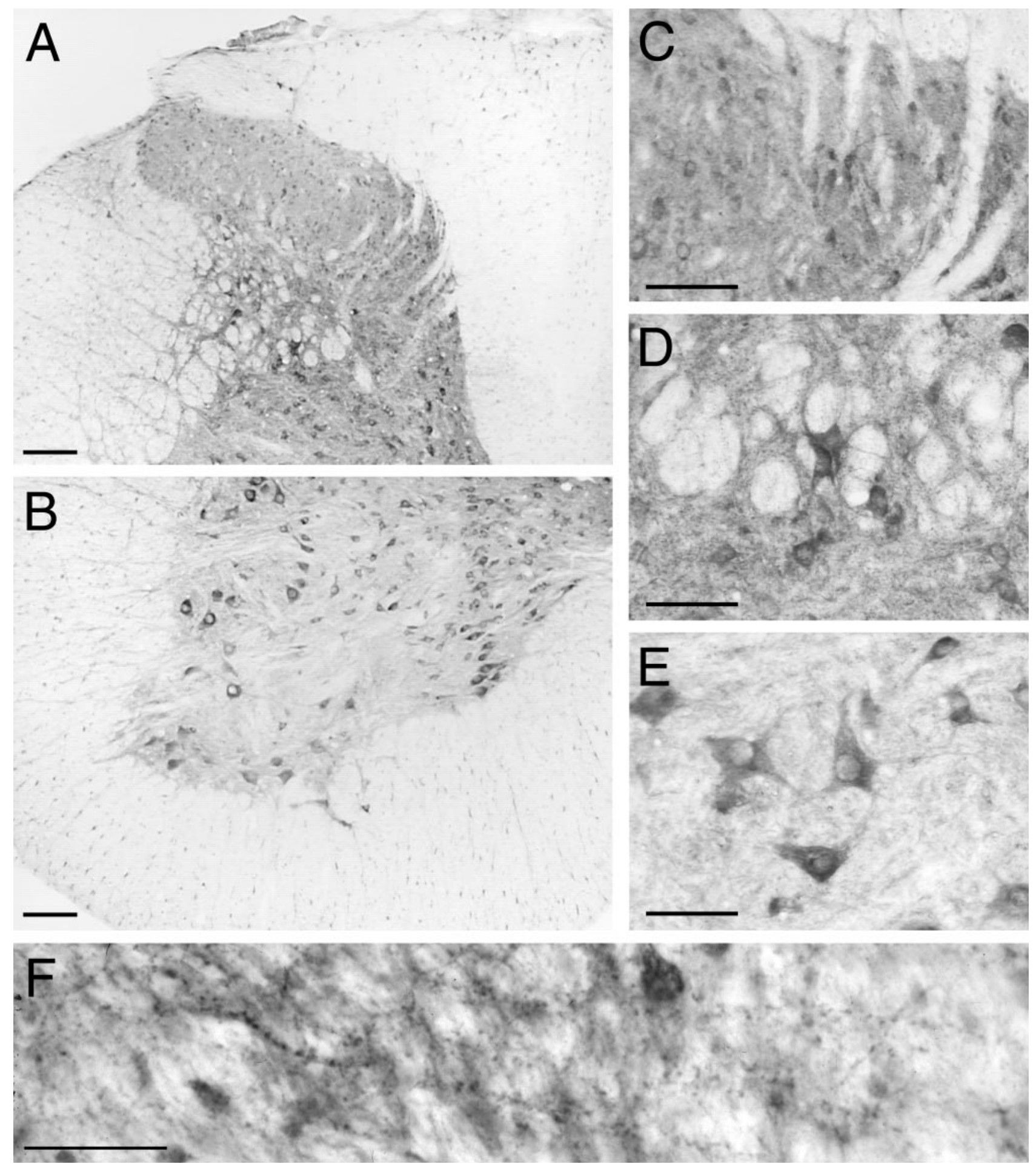

Figure 2. Distribution of netrin-1 protein in adult rat spinal cord. $A, B$, Distribution of netrin-1 immunoreactivity in dorsal $(A)$ and ventral $(B)$ C7 adult rat spinal cord is shown. Netrin-1 immunoreactivity was associated with a heterogeneous population of cell bodies throughout the spinal gray matter and a uniform population in the white matter. $C, D, F$, Fibrous and punctate immunoreactivity was detected in the neuropil $(C, D)$, including immunoreactivity associated with fine processes and with larger neurites that have a beads-on-a-string morphology characteristic of synaptic varicosities $(F$; cervical nucleus and lateral spinal nucleus at C7). $E$, In the ventral horn of the gray matter, netrin-immunoreactive cell bodies and processes characteristic of motoneurons were detected. $A, B$, In the white matter, a uniform population of small cell bodies and their processes were netrin-1 positive. Bright-field optics, visualized with a POD-conjugated secondary antibody and diaminobenzidine substrate, is shown. Objective magnification: $A, B, 10 \times ; C-F, 40 \times$. Scale bars: $A, B, 100 \mu \mathrm{m} ; C-E, 50 \mu \mathrm{m} ; F, 30 \mu \mathrm{m}$.

web of netrin-immunoreactive processes with morphological characteristics of dendrites and larger immunopositive neurites with a beads-on-a-string appearance characteristic of synaptic varicosities (Fig. 2F). Cell bodies and processes of motor neurons in the ventral horn were also clearly netrin immunoreactive. This staining included neurites within the gray matter with dendritic 
Figure 3. Netrin-1 expression by neurons. Coimmunolabeling for netrin (PN2) and the neuronal marker NeuN illustrates a close association of netrin protein with neurons in all laminas of the adult spinal cord. Hemisections of C7 rat dorsal spinal cord $(A, B)$ and ventral spinal cord $(C, D)$ are double immunolabeled for netrin $(A, C)$ and the neuronal-specific marker NeuN $(B, D)$. In the gray matter, many NeuN-positive neurons are netrin positive; however NeuN-negative, netrin-positive cells are also present throughout the gray and the white matter. Confocal microscopy, with Cy3- and FITC-coupled secondary antibodies, is shown. Objective magnification, $10 \times$. Scale bars, $250 \mu \mathrm{m}$.

Figure 4. Netrin-1 is not expressed by astrocytes. Double immunolabeling for netrin and the astrocytic marker GFAP indicates that netrin is not expressed by astrocytes. $A$, The distribution of netrin protein $(r e d)$ in the ventral spinal cord of an adult rat. The dashed line delineates the border between the gray matter of the ventral horn (above) and the spinal white matter. $B$, The distribution of astrocytes indicated by GFAP immunoreactivity ( green). $C$, The absence of colabeling between netrin-immunoreactive cells in spinal white matter and GFAP-positive astrocytes. $D$, A magnification of the central portion of $C$, illustrating that although the GFAP-positive and netrin-1-positive processes are often intertwined, they are distinctly separate. Confocal microscopy, with Cy3- and FITC-coupled secondary antibodies, is shown. Objective magnification, $20 \times$. Scale bar, $100 \mu \mathrm{m}$.
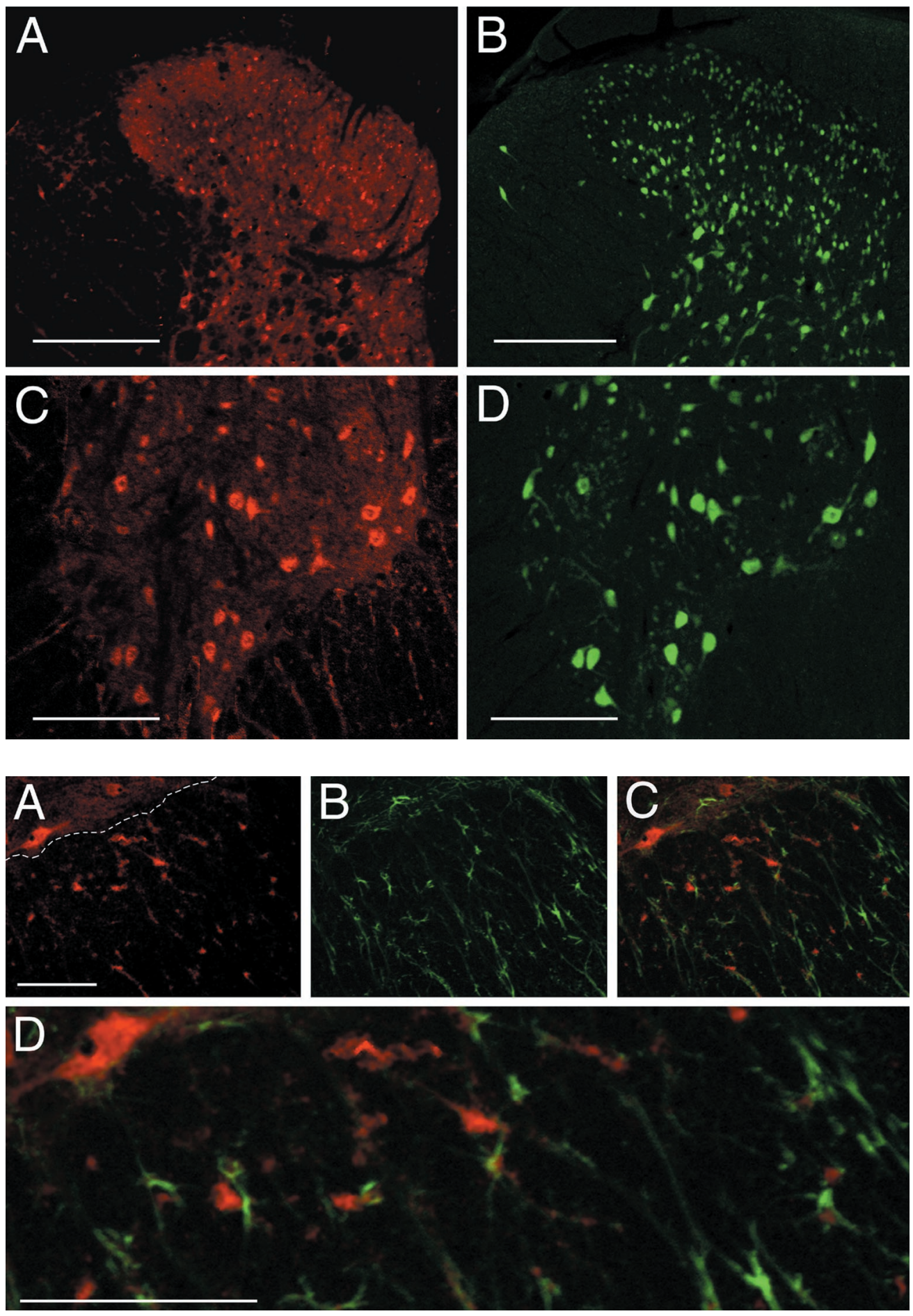

morphology and immunopositive axons projecting out of the gray matter (Fig. 2B,E).

Sections of rat spinal cord were then double-labeled with antibodies against netrin and immunohistochemical markers for neuronal or glial cells. Double labeling using a monoclonal antibody against the neuronal-specific antigen $\mathrm{NeuN}$ and the polyclonal netrin antibody PN2 confirmed that many of the immunopositive cells in the adult spinal cord gray matter were neurons (Fig. 3). However, a subset of small netrin-positive, NeuN-negative cells in the gray matter were morphologically similar to the netrin-1expressing cells present in white matter.
Immunohistochemical markers that differentiate between glial cell types were used to identify the netrin-1-expressing cells in the spinal white matter. No colabeling was found between netrin-1positive cells and GFAP-positive astrocytes (Fig. 4). In contrast, an antibody against the oligodendroglial marker CNP (Vogel and Thompson, 1988) labeled all of the netrin-immunoreactive cells observed in the white matter of the adult rat spinal cord (Fig. $5 F-H)$.

To confirm the identity of these cells, we used a line of mice carrying a transgene that marks the oligodendrocyte lineage. These mice contain a $l a c Z$ reporter gene that has been "knocked 

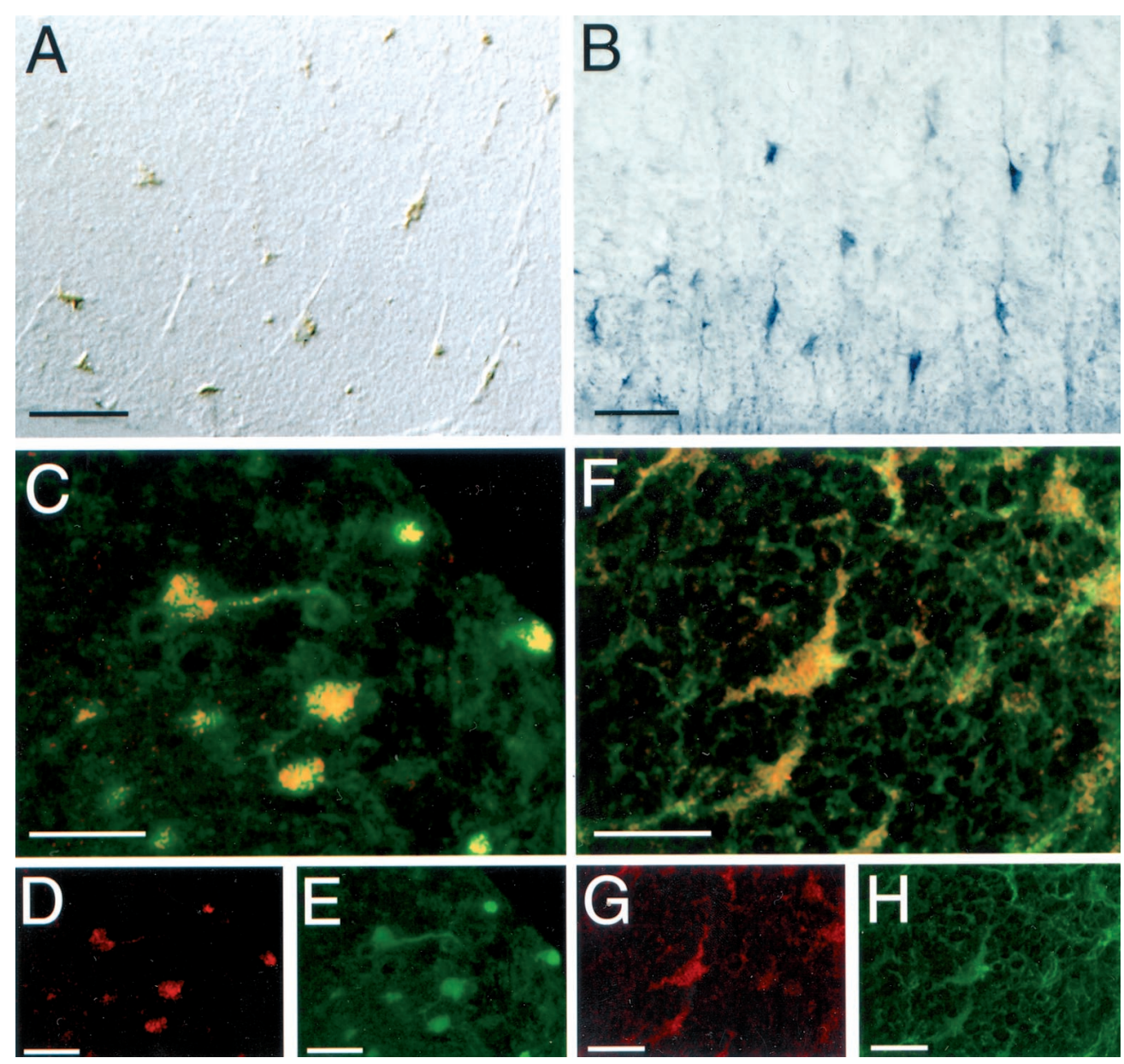

Figure 5. Oligodendroctyes express netrin-1 in the adult spinal cord. $A$, In situ hybridization showing the distribution of netrin-1-expressing cells in white matter at the ventral edge of the adult rat cervical spinal cord. $B$, Distribution of netrin immunoreactivity in a similar section of cervical spinal cord. $A$ and $B$ are visualized with POD and DAB. $C-E, A$ transgenic mouse line that marks the oligodendroglial lineage by expression of lac $Z$ used to determine the relationship between netrin-1 expression and oligodendrocytes. $D$, Confocal analysis of netrin-1 immunoreactivity (red, Cy3conjugated secondary antibody). $E$, $\beta$-Gal immunoreactivity marking oligodendrocytes (green, FITC-conjugated secondary antibody). $C$, Superimposition of $D$ and $E$ showing netrin1-immunoreactive oligodendrocytes. $F-H$, Confocal image analysis of double-labeled immunoreactivity in the adult rat spinal cord of netrin and the oligodendrocyte marker CNP. $G, \mathrm{Ne}-$ trin-1 immunoreactivity (red, Cy3conjugated secondary antibody). $H$, Distribution of CNP immunoreactivity (green, FITC-conjugated secondary antibody). $A$, DIC optics. $B$, Bright-field optics, POD-conjugated secondary antibody and DAB. $C-H$, Confocal microscopy. Objective magnification: $A, B, 40 \times ; C-H, 100 \times$. Scale bars: $A, B, 50 \mu \mathrm{m} ; C-H, 25 \mu \mathrm{m}$. in" and replaces the first exon of the $M B P$ gene (Bachnou et al., 1997). LacZ expression is driven by the endogenous MBP promoter, and $\beta$-gal accumulation serves as a sensitive marker to identify oligodendrocytes. Although the interrupted locus is null for $M B P$ and mice lacking MBP have the shiverer phenotype because of myelin deficiency (Roach et al., 1985), heterozygous knock-in mice are normal and were used for our analysis. Netrin-1 immunoreactivity colocalized with $\beta$-gal immunoreactivity in both the white (Fig. $5 C-E$ ) and the gray matter (data not shown) of the spinal cord. In both adult rats and the MBP-lacZ transgenic mice, extensive analysis of colabeling along the full rostrocaudal extent of the spinal cord showed no discordance between the coexpression of oligodendrocyte markers and netrin, indicating that most, if not all, oligodendrocytes in the adult spinal cord constitutively express netrin-1.

\section{Time course of postnatal netrin expression}

We performed a developmental time course of postnatal netrin-1 protein expression in the rat spinal cord using Western blot analysis (Fig. 6A). Similar amounts of full-length netrin-1 protein were detected in the newborn [postnatal day $0(\mathrm{P} 0)$ ] through to adulthood. A small but distinct shift $(\sim 80$ to $\sim 75 \mathrm{kDa})$ in the mobility of netrin-1 protein occurs at approximately P14. We have found no evidence that netrin-1 mRNA is alternatively spliced in either the developing or adult CNS, raising the possibility that netrin-1 may undergo different post-translational processing in the embryo compared with the adult, possibly by limited proteolysis or differential glycosylation. Several potential
$\mathrm{N}$-linked glycosylation sites are conserved in mammalian netrin-1 sequences. Although the $\sim 75 \mathrm{kDa}$ band is the predominant species found in the adult, the enrichment produced by subcellular fractionation (described below) revealed the presence of both immunoreactive bands in the adult nervous system (Fig. 6B, lane 8 ). It may be the case that both variants are produced in the adult CNS or alternatively that the higher molecular weight protein corresponds to protein produced earlier in development that persists in the adult. Currently, little is known about the half-life of netrin-1 protein in any context.

\section{Netrin-1 protein is membrane-associated in the adult spinal cord}

The subcellular distribution of netrin-1 protein was identified using fractionation by differential centrif ugation of adult rat spinal cord homogenates (Fig. 6B). We followed the initial steps of a netrin purification protocol that was developed to isolate membranes derived from embryonic day 10 chick brains (Serafini et al., 1994). Although a secreted protein, netrin-1 was isolated from the membrane-associated fraction of the embryonic CNS (Serafini et al., 1994). To what extent netrin-1 protein is soluble or membrane-associated in the embryo has not yet been determined. The fractionation of adult rat spinal cord homogenates reported here indicates that the majority of netrin-1 in the adult CNS is not freely soluble. The results are consistent with much of the netrin-1 protein being membrane-associated or incorporated into an insoluble component of the extracellular matrix. After homogenization, full-length netrin-1 was detected in the LSP (Fig. 6B, 
Figure 6. Postnatal expression and subcellular enrichment of netrin protein. $A$, Western blot analysis of total spinal cord homogenates illustrates a developmental time course of netrin protein expression in postnatal and adult rat spinal cord. Lane 1 is derived from newborn rat spinal cord; lanes 2-4 are from P7, P14, and adult spinal cord, respectively. A small but distinct shift in the mobility of netrin occurs at approximately P14 ( $\sim 80$ to $\sim 75 \mathrm{kDa})$. PAGE $(10 \%)$ was used to separate $\sim 30 \mu \mathrm{g}$ of total protein loaded per lane. $B$, After homogenization of adult rat spinal cords, the low-speed spin yields an LSP (lane 1) and an LSS (lane 2). The medium-speed spin of the LSS yields an MSP (lane 3) and an MSS (lane 4). The high-speed spin of MSS yields the HSP (lane 5) containing microsomes and an HSS (lane 6) containing soluble proteins. High-salt extraction of the HSP and high-speed centrifugation yields the HSEP containing stripped microsomes, transmembrane proteins, and the microsomal contents (lane 7) and the HSES containing solubilized membrane-associated proteins (lane 8). PAGE (10\%) was used to separate $\sim 20 \mu \mathrm{g}$ of total protein loaded per lane. The same nitrocellulose membrane was reprobed multiple times to visualize the different markers shown. Below the immunoreactivity for netrin and each of the markers, the same blot is shown stained with Ponceau S, illustrating that comparable amounts of protein are present in each lane. The arrow indicates the approximate molecular weight of netrin-1. Molecular weight markers correspond to $116,97.4,66.2,45$, and $31 \mathrm{kDa}$.
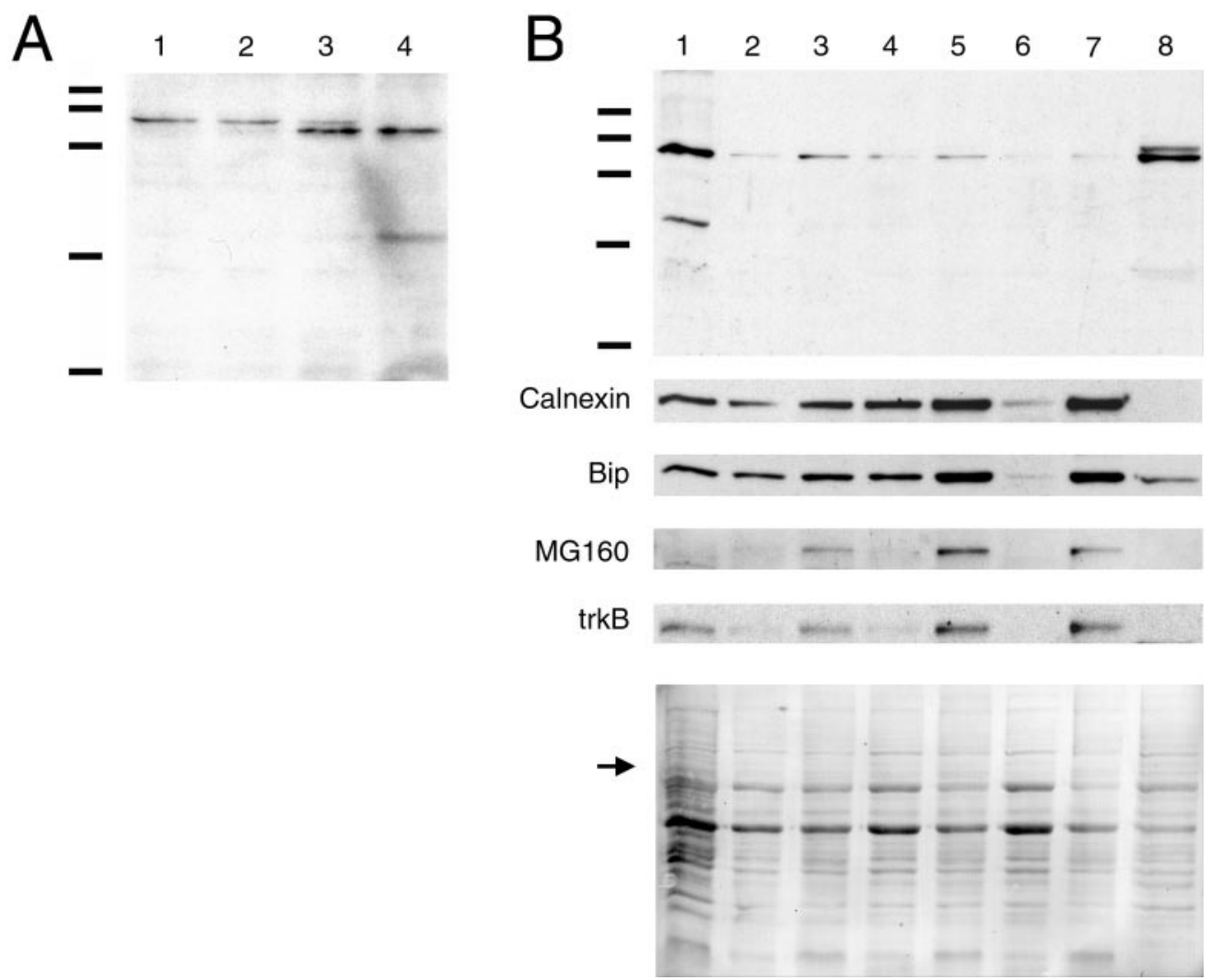

\begin{tabular}{|c|c|c|c|c|c|}
\hline Fraction & Volume $(\mathrm{ml})$ & Total protein $(\mathrm{mg})$ & OD units & $(\mathrm{OD} / \mathrm{mg})$ & $\sim$ Fold enrichment \\
\hline Homogenate & 6 & 62.0 & {$[8500]$} & 137 & 1 \\
\hline LSP & 10 & 21.5 & 20850 & 970 & 7.1 \\
\hline LSS & 5 & 42.2 & 1898 & 45 & 0.3 \\
\hline MSP & 6.5 & 28.5 & 5401 & 189 & 1.4 \\
\hline MSS & 8.5 & 18.1 & 2599 & 143 & 1.0 \\
\hline HSP & 4 & 5.0 & 3809 & 756 & 5.5 \\
\hline HSS & 7.25 & 12.4 & 1756 & 142 & 1.0 \\
\hline HSEP & 1 & 2.6 & 2336 & 882 & 6.4 \\
\hline HSES & 4 & 1.4 & 28234 & 18949 & 138 \\
\hline
\end{tabular}

The table illustrates the relative enrichment of netrin-1 protein in the fractions shown in each of the lanes in Figure 6 . For each fraction, the total volume, the mass of total protein, the optical density (OD) of the netrin-1-immunoreactive band, the calculated netrin-1 OD/mg, and the approximate fold enrichment of netrin-1 are listed. The OD for the total protein homogenate was estimated, indicated by brackets, by summing the OD units measured for the LSP and LSS.

lane 1) that contains a heterogeneous mixture of nuclei, intact cells, large cellular debris, and extracellular matrix. After the high-speed spin that separates membranous microsomes from soluble proteins, an immunoreactive band corresponding to the molecular weight of full-length netrin-1 ( $\sim 75 \mathrm{kDa})$ was enriched in the HSP (Fig. 6B, lane 5) relative to the HSS (Fig. 6B, lane 6). The microsomes in the HSP fraction are derived from a mixture of cellular membranes that include the plasma membrane, endoplasmic reticulum, and Golgi apparatus. Calnexin and MG-160 are integral membrane proteins of the ER and Golgi apparatus, respectively (Gonatas et al., 1989; Wada et al., 1991), and were appropriately enriched in the HSP (Fig. 6B, lane 5). TrkB, a tyrosine kinase that functions as a neurotrophin receptor at the plasma membrane (Klein et al., 1991) was similarly enriched in the HSP fraction. After high-salt extraction of the HSP to solubilize membrane-associated proteins, these transmembrane proteins all partitioned into the HSEP fraction (Fig. 6B, lane 7), appropriately remaining with the membranes. BiP, a soluble ER resident protein (Munro and Pelham, 1986), was also enriched in the HSP and HSEP fractions, indicating that proteins contained within the lumen of the ER largely remain associated with the membrane fraction. This suggests that most ER microsomes reform to retain their contents and are not lysed by either homogenization or high-salt extraction. After high-salt extraction of the HSP, the majority of netrin-1 protein was stripped from the membranes and partitioned into the HSES (Fig. 6B, lane 8). 

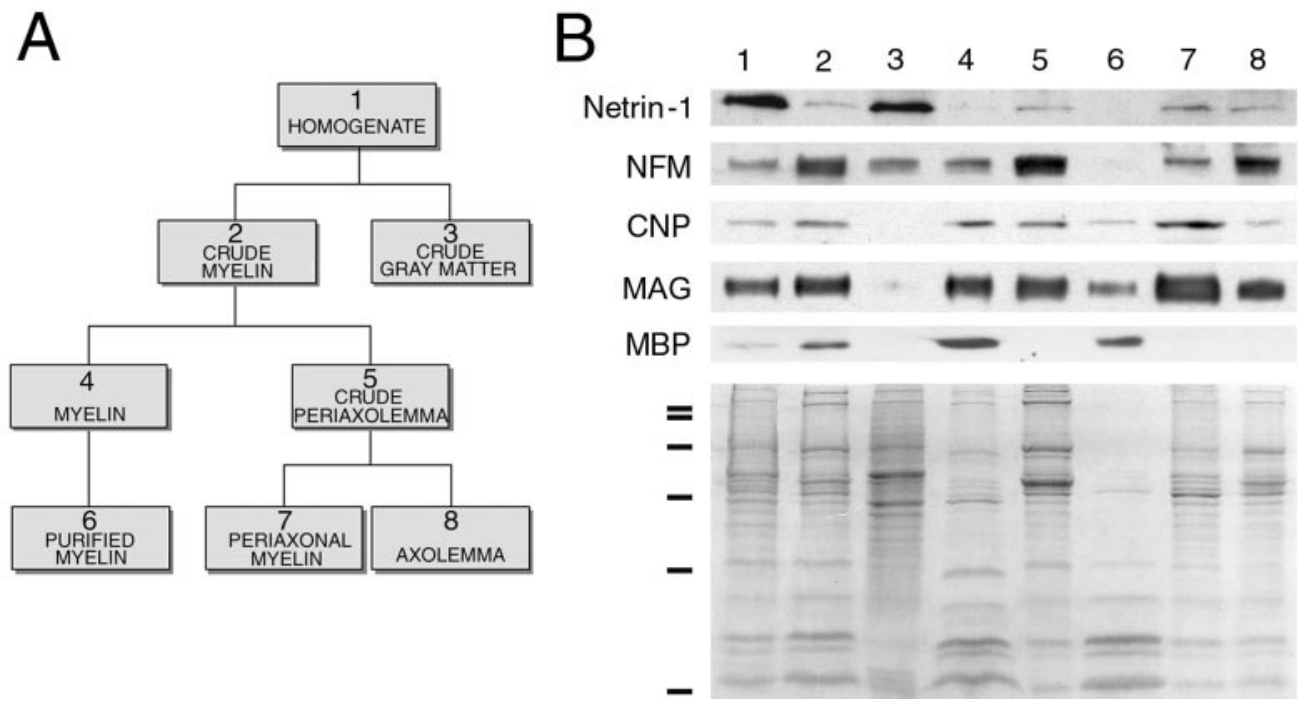

Figure 7. Netrin-1 is enriched in periaxonal myelin. $A$, The flow chart illustrates the origin of the fractions containing purified myelin, periaxonal myelin, and axolemma. Each step is labeled with the number corresponding to the lane on the gel in $B$ containing that fraction. $B$, The proteins $\mathrm{MBP}(\sim 14$ $\mathrm{kDa}), \mathrm{CNP}(\sim 46 \mathrm{kDa}), \mathrm{MAG}(\sim 100$ $\mathrm{kDa})$, and $\mathrm{NFM}(\sim 145 \mathrm{kDa})$ were used as markers for the enrichment of purified myelin (compact myelin), periaxonal myelin, and axolemmal membranes, respectively. Full-length netrin-1 protein partitioned between the crude myelin (lane 2) and crude gray matter (lane 3) fractions. After separation of the crude white matter fraction into myelin (lane 4 ) and crude periaxolemma (lane 5), netrin-1 ( $\sim 75$ $\mathrm{kDa}$ ) was enriched in the crude periaxolemmal fraction. No netrin immunoreactivity was detected in the purified myelin fraction containing compact myelin (lane 6). After further fractionation of the crude periaxolemmal myelin, full-length netrin-1 partitioned between the fractions enriched for periaxonal myelin (lane 7 ) and axolemma (lane 8). A $10 \%$ and a $12 \%$ acrylamide gel were used to separate $\sim 20 \mu \mathrm{g}$ of total protein loaded per lane to visualize the different markers shown. Below the immunoblots, a $12 \%$ gel containing these fractions is shown stained with Coomassie blue, illustrating the distribution of proteins in each fraction and that comparable amounts of protein are present in each lane. Molecular weight markers correspond to 116, 97.4, 66.2, 45, 31, and $21 \mathrm{kDa}$.

Densitometric analysis indicated that netrin-1 is enriched $\sim 25$ fold in the HSES fraction compared with the HSP and $\sim 140$ fold in the HSES compared with the homogenate (Table 1). A small amount of netrin- 1 protein remained associated with the microsomal membranes in the HSEP. This may correspond to netrin- 1 in vesicles that had not yet been secreted from the cell, to netrin-1 inside an endosomal compartment of the cell, or to netrin-1 within vesicles derived from plasma membrane that resealed in an outside-in configuration after homogenization. The presence of some netrin-1 protein within an intracellular membrane-bound compartment is consistent with the results shown in Figure 2, illustrating the presence of netrin-1 immunoreactivity in the cytoplasm of many cells. In summary, the fractionation results obtained are consistent with the majority of netrin-1 protein in the adult spinal cord being associated with the exterior surface of cellular plasma membranes or the ECM.

\section{Netrin-1 protein is associated with periaxonal myelin}

To characterize the distribution of netrin- 1 in the white matter, we performed myelin fractionation experiments. Following a series of steps described schematically in Figure $7 A$, we produced final fractions enriched for compact myelin, periaxonal myelin, and axolemma following a protocol described by Sapirstein et al. (1992). Fractions enriched for crude gray matter and crude myelin were generated first (Fig. 7B, lanes 2,3). From the crude myelin, fractions enriched for myelin and crude periaxolemma were produced (Fig. 7B, lanes 4,5). The myelin fraction was further processed to yield the purified myelin fraction (Fig. 7B, lane 6) that is highly enriched for compact myelin. The crude periaxolemmal fraction (Fig. 7B, lane 5) is the precursor to fractions enriched for periaxonal myelin and axolemma (Fig. $7 B$, lanes 7,8 ). The periaxonal myelin fraction is enriched for oligodendrocyte membranes apposed to the periaxonal space, whereas the axolemmal fraction is enriched for axonal membranes derived from myelinated axons. MBP was used as a marker for fractions containing compact myelin (Yin et al., 1997). MBP was appropriately en- riched in the purified myelin fraction (Fig. 7B, lane 6). MAG, a transmembrane protein, and CNP, a cytoplasmic plasma membrane-associated enzyme, were used as markers enriched in periaxonal myelin (Trapp et al., 1988; Bartsch et al., 1989), and NFM was used as a marker for axons (Lee and Cleveland, 1996). Here, CNP and MAG were appropriately enriched in the periaxonal myelin fraction and NFM in the axolemmal fraction (Fig. 7B, lanes 7,8), confirming that components of these fractions partitioned as expected. After fractionation of crude myelin into the myelin and crude periaxolemmal fractions, netrin-1 was enriched in the latter fraction (Fig. 7B, lane 5 ) with barely detectable levels present in the myelin fraction (Fig. 7B, lane 4). After further purification, netrin-1 was not detected in the purified myelin fraction (Fig. 7B, lane 6). Consistent with this result, we did not detect netrin-1 protein in preparations of purified compact myelin prepared using an alternative method described by Norton and Poduslo (1973) (data not shown). Netrin-1 protein could be detected in both the axolemmal and periaxonal myelin membrane fractions (Fig. 7B, lanes 7,8) after further fractionation of crude periaxolemma. The distribution found after fractionation is consistent with the netrin-1 staining detected in the white matter immunohistochemically (Fig. 5B). In agreement with the results of fractionation, compact myelin did not stain. However, many small immunoreactive dots and, more rarely, thin linear positive profiles were detected throughout the white matter, consistent with the presence of netrin-1 within the proximal processes of oligodendrocyte arms and the periaxonal space (Fig. 5B). Although ultrastructural analysis using immunoelectron microscopy will have to be performed to determine the precise subcellular localization of netrin-1 protein, the findings presented here demonstrate that full-length netrin-1 protein is excluded from compact myelin and suggest that netrin-1 is present in the periaxonal space associated with the membrane surfaces of oligodendrocytes and axons. 


\section{DISCUSSION}

\section{Netrins: secreted proteins with long-range and short-range actions}

Netrins are bifunctional cues, attracting the growth of some axons and repelling that of others. Netrin- 1 protein secreted by the floor plate has been proposed to form a gradient that orients the growth of circumferentially extending axons in the developing neural tube (Kennedy et al., 1994; Colamarino and TessierLavigne, 1995a). In support of this, netrin-1 secreted by cells in vitro acts as a long-range cue to attract or repel the axons of different types of neurons (Kennedy et al., 1994; Colamarino and Tessier-Lavigne, 1995a; Shirasaki et al., 1996; Deiner et al., 1997; Metin et al., 1997; Varela-Echavarria et al., 1997; Wang et al., 1999). These assays suggest that netrin-1 protein can diffuse at least $250 \mu \mathrm{m}$ from the source of netrin-1 synthesis (Placzek et al., 1990; Kennedy et al., 1994). Consistent with this, loss of netrin-1 or DCC function in vivo disrupts the normal establishment of long-distance axonal projections, including those that grow to the floor plate and pioneer the ventral commissure of the spinal cord (Serafini et al., 1996; Fazeli et al., 1997).

Here we describe widespread constitutive expression of netrin- 1 by neurons and oligodendrocytes in the adult mammalian spinal cord. Furthermore, the level of netrin- 1 mRNA detected was similar to that found in the embryonic CNS. However, subcellular fractionation indicated that the majority of netrin-1 protein present in the adult CNS is not freely soluble. In the adult, newly synthesized netrin-1 protein may be externalized already bound to a component of the cell surface, or alternatively, it may be diff usible immediately after secretion but then captured by a component of the ECM or the cell surface. In either case, these results suggest that much of the netrin- 1 protein present is bound to either the surface of the cell secreting the protein or the surface of a nearby cell. By definition, this distribution suggests a short-range function for netrin-1 in the adult CNS. As such, this may have more in common with the short-range role of netrin regulating the development of neuromuscular synapses in $D$. melanogaster (Winberg et al., 1998) than with the function of netrin as a long-range axon guidance cue in the embryonic spinal cord (Kennedy et al., 1994; Serafini et al., 1996). In the study by Winberg et al. (1998), netrin was found to act as a short-range target-derived cue regulating the formation of nerve $\rightarrow$ muscle synapses in a concentration-dependent manner. The distribution described here suggests that a major function of netrin-1 in the adult mammalian CNS may be to similarly regulate cell-cell interactions, including synaptic connections and axon-glial interactions.

For netrin-1 to function as a short-range cue, netrin receptors must be expressed by nearby cells. DCC expression has been reported in the adult human spinal cord, although the specific cell types involved were not identified (Hedrick et al., 1994). Consistent with this observation, we have found that Dcc and the netrin receptors neogenin, unc5h1, and unc5h2 are all constitutively expressed in the adult rat spinal cord (our unpublished data).

\section{Neurons in the adult spinal cord express netrin-1}

Our findings indicate that many neurons in the adult spinal cord, including motoneurons and multiple classes of interneurons, express readily detectable levels of netrin-1. Embryonic commissural neurons express DCC and require netrin-1 to extend their axons to the floor plate (Serafini et al., 1996). In the adult rat, these commissural neurons are thought to become spinothalamic, spinoreticular, and spinocerebellar neurons (Altman and Bayer,
1984; for review, see Colamarino and Tessier-Lavigne, 1995b). Although embryonic commissural neurons do not express netrin-1 as their axons extend to the floor plate, our results suggest that these and many other classes of spinal interneurons express netrin-1 in the adult. During development in C. elegans, some pioneer neurons that extend an axon in response to a distant source of netrin/UNC-6 later express unc-6 themselves, and it has been suggested that this neuronal source of UNC-6 may influence the growth of other axons (Wadsworth et al., 1996). Furthermore, analysis of the distribution of netrin protein found in the developing CNS of D. melanogaster indicates that frazzled, the fly homolog of DCC, can capture netrin and present it locally along the surface of an axon. This results in a restricted distribution of netrin that functions to guide later-extending axons (Hiramoto et al., 2000). These results indicate that netrin on the surface of a neuron can affect the behavior of an adjacent cell. They also raise the possibility that in the mammalian CNS, the distribution of netrin protein may be influenced by the distribution of receptors, such as DCC and neogenin, that may function to localize and present netrin to nearby cells.

\section{Netrin-1 is expressed by oligodendrocytes and enriched in periaxonal myelin}

In addition to being expressed by neurons, we report that most, if not all, oligodendrocytes in the adult spinal cord express netrin-1. Furthermore, fractionation of adult spinal cord white matter indicated that full-length netrin-1 protein is excluded from compact myelin but may be localized to the periaxonal space, the interface between axons and oligodendroglia. The intimate apposition between oligodendrocytes and axons constitutes one of the most extensive intercellular specializations in the CNS. The membranes associated with myelinated axons can be divided into at least three types: compact myelin, periaxonal myelin, and axolemma. Compact myelin is a specialized, but enzymatically inactive, structure. In contrast, the oligodendrocyte membrane facing the periaxonal space is specifically enriched with proteins such as CNP and MAG, proteins that appear to be required for the maintenance of interactions between axonal and oligodendroglial membranes (Yin et al., 1997; Schachner and Bartsch, 2000). Immediately before myelination begins, the interaction between the axon and its ensheathing oligodendrocyte must involve both surface recognition and adhesive affinity. The expression of netrin- 1 by adult oligodendrocytes suggests that it may regulate oligodendrocyte motility during development or influence myelination. Understanding this role of netrin-1 may provide insight into the development of strategies that promote remyelination in diseases such as multiple sclerosis.

The presence of netrin- 1 in the CNS may also influence the ability of axons to regenerate after injury. Although many CNS neurons have the capacity to regenerate a severed axon (David and Aguayo, 1981), the onset of myelination in the mammalian CNS coincides with a dramatic drop in the ability of injured axons to regenerate. Substantial evidence indicates that CNS white matter contains factors that inhibit axon outgrowth (for review, see Schwab et al., 1993), and multiple inhibitory components of myelin have been identified (McKerracher et al., 1994; Mukhopadhyay et al., 1994; Chen et al., 2000; GrandPre et al., 2000; Prinjha et al., 2000). Interestingly, two of these inhibitors, MAG and Nogo, are constitutively expressed by oligodendrocytes in the adult CNS and enriched in periaxonal myelin (Bartsch et al., 1989; Chen et al., 2000). The expression of netrin-1 by mature oligodendrocytes and its presence in periaxonal myelin suggest 
that myelin-associated netrin-1 may restrict axonal sprouting in the adult CNS, perhaps via a mechanism analogous to axonal chemorepulsion during development. Such a function in the normal CNS may translate into inhibition of regeneration after injury.

\section{Netrin: a role at the cell surface mediating cell-cell interactions?}

Here we have identified the cell types that express netrin- 1 in the adult spinal cord; however, both netrin-1 and DCC are also expressed outside the nervous system (Hedrick et al., 1994; Kennedy et al., 1994; Reale et al., 1994; Meyerhardt et al., 1999; Wang et al., 1999). DCC was first identified as a candidate tumor suppressor deleted in some forms of colorectal cancer (Fearon et al., 1990; Hedrick et al., 1994). Loss of DCC expression occurs with the progression of multiple types of cancer, including glial carcinomas (Scheck and Coons, 1993; Ekstrand et al., 1995; for review, see Cho and Fearon, 1995; Reyes-Mugica et al., 1997). Furthermore, mutation or strongly reduced expression of netrin-1 has been found in some human glioblastomas and neuroblastomas (Meyerhardt et al., 1999), and although controversial, recent findings continue to support a role for DCC as a tumor suppressor (Hilgers et al., 2000). As such, the short-range function for netrin-1 emphasized here, mediating neuron-neuron and neuron-glial interactions in the adult CNS, may be representative of a wider role for netrin-DCC interactions regulating cell-cell contact in multiple tissue types.

\section{REFERENCES}

Ackerman SL, Kozak LP, Przyborski SA, Rund LA, Boyer BB, Knowles BB (1997) The mouse rostral cerebellar malformation gene encodes an UNC-5-like protein. Nature 386:838-842.

Altman J, Bayer SA (1984) The development of the rat spinal cord. Adv Anat Embryol Cell Biol 85:1-164.

Ausubel FM, Brent R, Kingston RE, Moore DD, Seidman JG, Smith JA, Struhl K (1990) Current protocols in molecular biology. New York: Wiley.

Bachnou N, Schwartz Z, Farhdi H, Peterson A (1997) Developmental programming of a myelin gene revealed at high resolution in MBP "knock-in" mice. In: Mystic Connecticut: ISN satellite and U ConnKroc, Symposium abstracts, pp 79.

Bartsch U, Kirchoff F, Schachner M (1989) Immunohistological localization of the adhesion molecules L1, N-CAM, and MAG in the developing and adult optic nerve of mice. J Comp Neurol 284:451-462.

Bonaldo MF, Lennon G, Soares MB (1996) Normalization and subtraction: two approaches to facilitate gene discovery. Genome Res 6:791-806.

Braissant O, Wahli W (1998) A simplified in situ hybridization protocol using non-radioactively labeled probes to detect abundant and rare mRNAs on tissue sections. Biochemica 1:10-16.

Chan SSY, Zheng H, Su MW, Wilk R, Kileen MT, Hegdecock EM, Culotti JG (1996) UNC-40, a C. elegans homolog of DCC (deleted in colorectal cancer), is required in motile cells responding to UNC-6 netrin cues. Cell 87:187-195.

Chen MS, Huber AB, van der Haar ME, Frank M, Schnell L, Spillman AA, Christ F, Schwab ME (2000) Nogo-A is a myelin-associated neurite outgrowth inhibitor and an antigen for monoclonal antibody IN-1. Nature 403:434-439.

Cho KR, Fearon ER (1995) DCC: linking tumor suppressor genes and altered cell surface interactions in cancer? Curr Opin Genet Dev 5:72-78.

Clancy B, Cauller LJ (1998) Reduction of background autofluorescence in brain sections following immersion in sodium borohydride. J Neurosci Methods 83:97-102

Colamarino SA, Tessier-Lavigne M (1995a) The axonal chemoattractant netrin-1 is also a chemorepellent for trochlear motor axons. Cell 81:621-629.

Colamarino SA, Tessier-Lavigne M (1995b) The role of the floor plate in axon guidance. Annu Rev Neurosci 18:497-529.

Colavita A, Culotti JG (1998) Suppressors of ectopic UNC-5 growth cone steering identify eight genes involved in axon guidance in Caenorhabditis elegans. Dev Biol 194:72-85.

Croul S, Mezitis SGE, Stieber A, Chen Y, Gonatas JO, Goud B, Gonatas NK (1990) Immunocytochemical visualization of the Golgi apparatus in several species, including human, and tissues with antiserum against
MG-160, a sialoglycoprotein of rat Golgi apparatus. J Histochem Cytochem 38:957-963.

David S, Aguayo AJ (1981) Axonal elongation into peripheral nervous system "bridges" after central nervous system injury in adult rats. Science 214:931-933.

Deiner MS, Kennedy TE, Fazeli A, Serafini T, Skarnes WC, TessierLavigne M, Sretevan DW (1997) Netrin-1 and DCC mediate axon guidance at the optic disc: loss of function leads to optic nerve hypoplasia. Neuron 19:575-589.

de la Torre J, Hopker V, Ming G, Poo M, Tessier-Lavigne M, HemmatiBrivanlou A, Holt C (1997) Turning of retinal growth cones in a netrin-1 gradient mediated by the netrin receptor DCC. Neuron 19:1211-1224.

Detskey PZ, Bigbee JW, DeVries GH (1988) Isolation and characterization of axolemma-enriched fractions from discrete areas of bovine CNS. Neurochem Res 13:449-454.

Ekstrand BC, Mansfield TA, Bigner SH, Fearon ER (1995) DCC expression is altered by multiple mechanisms in brain tumours. Oncogene 11:2393-2402.

Fazeli A, Dickinson SL, Hermiston ML, Tighe RV, Steen RG, Small CG, Stoeckli ET, Keino-Masu K, Masu M, Rayburn H, Simons J, Bronson RT, Gordon JI, Tessier-Lavigne M, Weinberg RA (1997) Phenotype of mice lacking functional Deleted in colorectal cancer (Dcc) gene. Nature 386:796-804

Fearon ER, Cho KR, Nigro JM, Kern SE, Simons JW, Ruppert JM, Hamilton SR, Preisinger AC, Thomas G, Kinzler KW, Vogelstein B (1990) Identification of a chromosome $18 \mathrm{q}$ gene that is altered in colorectal cancers. Science 247:49-56.

Gonatas JO, Mezitis SG, Stieber A, Fleischer B, Gonatas NK (1989) MG-160. A novel sialoglycoprotein of the medial cisternae of the Golgi apparatus. J Biol Chem 264:646-653.

GrandPre T, Nakamura F, Vartanian T, Strittmatter SM (2000) Identification of the Nogo inhibitor of axon regeneration as a Reticulon protein. Nature 403:439-444.

Hedgecock EM, Culotti JG, Hall DH (1990) The unc-5, unc-6, and unc-40 genes guide circumferential migrations of pioneer axons and mesodermal cells on the epidermis in C. elegans. Neuron 4:61-85.

Hedrick L, Cho KR, Fearon ER, Wu TC, Kinzler KW, Vogelstein B (1994) The DCC gene product in cellular differentiation and colorectal tumorigenesis. Genes Dev 8:1174-1183.

Hendershot LM, Wei J-Y, Gaut JR, Lawson B, Freiden PJ, Murti KG (1995) In vivo expression of mammalian BiP ATPase mutants causes disruption of the endoplasmic reticulum. Mol Biol Cell 6:283-296.

Hilgers W, Song JJ, Haye M, Hruban RR, Kern SE, Fearon ER (2000) Homozygous deletions inactivate DCC, but not MADH4/DPC4/ SMAD4, in a subset of pancreatic and biliary cancers. Genes Chromosomes Cancer 27:353-357.

Hiramoto M, Hiromi Y, Giniger E, Hotta Y (2000) The Drosophila netrin receptor frazzled guides axons by controlling netrin distribution. Nature 406:886-889.

Hong K, Hinck L, Nishiyama M, Poo M, Tessier-Lavigne M, Stein E (1999) A ligand-gated association between cytoplasmic domains of UNC5 and DCC family receptors converts netrin-induced growth cone attraction to repulsion. Cell 97:927-941.

Ishii N, Wadsworth WG, Stern BD, Culotti JG, Hedgecock EM (1992) UNC-6, a laminin-related protein, guides cell and pioneer axons and mesodermal cells on the epidermis in C. elegans. Neuron 4:61-85.

Keino-Masu K, Masu M, Hinck L, Leonardo ED, Chan SSY, Culotti JG, Tessier-Lavinge M (1996) Deleted in colorectal cancer (DCC) encodes a netrin receptor. Cell 87:175-185.

Kennedy TE (2000) Cellular mechanisms of netrin function: long-range and short-range actions. Biochem Cell Biol 78:569-575.

Kennedy TE, Serafini T, de la Torre JR, Tessier-Lavigne M (1994) Netrins are diff usible chemotropic factors for commissural axons in the embryonic spinal cord. Cell 78:425-435.

Klein R, Nanduri V, Jing SA, Lamballe F, Tapley P, Bryant S, CordonCardo C, Jones KR, Reichardt LF, Barbacid M (1991) The trkB tyrosine protein kinase is a receptor for brain-derived neurotrophic factor and neurotrophin-3. Cell 66:395-403.

Koch M, Murrell JR, Hunter DD, Olson PF, Jin W, Keene DR, Brunken WJ, Burgeson RE (2000) A novel member of the netrin family, betanetrin, shares homology with the beta chain of laminin: identification, expression, and functional characterization. J Cell Biol 151:221-234.

Lee MK, Cleveland DW (1996) Neuronal intermediate filaments. Annu Rev Neurosci 19:187-217.

Leonardo ED, Hinck L, Masu M, Keino-Masu K, Ackerman SL, TessierLavigne M (1997) Vertebrate homologues of C. elegans unc-5 are candidate netrin receptors. Nature 386:833-838.

Leung-Hagesteijn C, Spence AM, Stern BD, Zhou Y, Su MW, Hedgecock EM, Culotti JG (1992) UNC-5, a transmembrane protein with immunoglobulin and thrombospondin type 1 domains, guides cell and pioneer axon migrations in C. elegans. Cell 71:289-299.

Livesey FJ, Hunt SP (1997) Netrin and netrin receptor expression in the embryonic mammalian nervous system suggests roles in retinal, striatal, nigral, and cerebellar development. Mol Cell Neurosci 8:417-429. 
McIntire SL, Garriga G, White J, Jacobson D, Horvitz HR (1992) Genes necessary for directed axonal elongation or fasciculation in C. elegans. Neuron 8:307-322.

McKerracher L, David S, Jackson DL, Kottis V, Dunn RJ, Braun PE (1994) Identification of myelin-associated glycoprotein as a major myelin-derived inhibitor of neurite growth. Neuron 13:805-811.

Metin C, Deleglise D, Serafini T, Kennedy TE, Tessier-Lavigne M (1997) A role for netrin-1 in the guidance of cortical efferents. Development 124:5063-5074.

Meyerhardt JA, Caca K, Eckstrand BC, Hu G, Lengauer C, Banavali S, Look AT, Fearon ER (1999) Netrin-1: interaction with deleted in colorectal cancer (DCC) and alterations in brain tumors and neuroblastomas. Cell Growth Differ 10:35-42.

Mukhopadhyay G, Doherty P, Walsh F, Crocker PR, Filibin MT (1994) A novel role for myelin-associated glycoprotein as an inhibitor of axonal regeneration. Neuron 13:757-767.

Munro S, Pelham HR (1986) An Hsp70-like protein in the ER: identity with the $78 \mathrm{kDa}$ glucose-regulated protein and immunoglobulin heavy chain binding protein. Cell 46:291-300.

Nakashiba T, Ikeda T, Nishimura S, Tashiro K, Honjo T, Culotti JG, Ithohara S (2000) Netrin-G1: a novel glycosyl phosphatidylinositollinked mammalian netrin that is functionally divergent from classical netrins. J Neurosci 20:6540-6550.

Norton WT, Poduslo SE (1973) Myelination in rat brain: method of myelin isolation. J Neurochem 21:749-757.

Paxinos G (1995) The rat nervous system, 2nd edition. San Diego: Academic.

Placzek M, Tessier-Lavigne M, Jessell T, Dodd J (1990) Orientation of commissural axons in vitro in response to a floor-plate derived chemoattractant. Development 110:19-30.

Prinjha R, Moore SE, Vinson M, Blake S, Morrow R, Christie G, Michalovich D, Simmons DL, Walsh FS (2000) Inhibitor of neurite outgrowth in humans. Nature 403:383-384.

Reale MA, Hu G, Zafar AI, Getzenberg RH, Levine SM, Fearon ER (1994) Expression and alternative splicing of the deleted in colorectal cancer $(D C C)$ gene in normal and malignant tissues. Cancer Res 54:4493-4501.

Reyes-Mugica M, Rieger-Christ K, Ohgaki H, Ekstrand BC, Helie M, Kleinman G, Yahanda A, Fearon ER, Kleihues P, Reale MA (1997) Loss of DCC expression and glioma progression. Cancer Res 57:382-386.

Roach A, Takahashi N, Pravtcheva D, Ruddle F, Hood L (1985) Chromosomal mapping of mouse myelin basic protein gene and structure and transcription of the partially deleted gene in shiverer mutant mice. Cell 42:149-155.

Sapirstein VS, Durrie R, Cherskey B, Beard ME, Flynn CJ, Fischer I (1992) Isolation and characterization of periaxolemmal and axolemmal enriched membrane fractions from the rat central nervous system. J Neurosci Res 32:593-604.

Schachner M, Bartsch U (2000) Multiple functions of the myelin- associated glycoprotein MAG (siglec-4a) in formation and maintenance of myelin. Glia 29:154-165.

Scheck AC, Coons SW (1993) Expression of the tumor suppressor gene $D C C$ in human gliomas. Cancer Res 53:5605-5609.

Schwab ME, Kapf hammer JP, Bandtlow CE (1993) Inhibitors of neurite growth. Annu Rev Neurosci 16:565-595.

Serafini T, Kennedy TE, Galko MJ, Mirzayan C, Jessell TM, TessierLavigne M (1994) The netrins define a family of axon outgrowthpromoting proteins homologous to C. elegans UNC-6. Cell 78:409-424.

Serafini T, Colamarino SA, Leonardo ED, Wang H, Beddington R, Skarnes WC, Tessier-Lavigne M (1996) Netrin-1 is required for commissural axon guidance in the developing vertebrate nervous system. Cell 87:1001-1014.

Shirasaki R, Mirzayan C, Tessier-Lavigne M, Murakami F (1996) Guidance of circumferentially growing axons by netrin-dependent and -independent floor plate chemotropism in the vertebrate brain. Neuron 17:1079-1088.

Trapp BD, Bernier L, Andrews SB, Colman DR (1988) Cellular and subcellular distribution of $2^{\prime}, 3^{\prime}$-cyclic nucleotide $3^{\prime}$-phosphodiesterase and its mRNA in the rat central nervous system. J Neurochem $51: 859-868$.

van Raay TJ, Foskett SM, Connors TD, Klinger KW, Landes GM, Burn TC (1997) The NTN2L gene encoding a novel human netrin maps to the autosomal dominant polycystic kidney disease region on chromosome 16p13.3. Genomics 41:279-282.

Varela-Echavarria A, Tucker A, Puschel AW, Guthrie S (1997) Motor axon subpopulations respond differentially to the chemorepellents netrin-1 and semaphorin D. Neuron 18:193-207.

Vogel US, Thompson RJ (1988) Molecular structure, localization, and possible functions of the myelin-associated enzyme $2^{\prime}, 3^{\prime}$-cyclic nucleotide 3'-phosphodiesterase. J Neurochem 50:1667-1677.

Wada I, Rindress D, Cameron PH, Ou WJ, Doherty II JJ, Louvard D, Bell AW, Dignard D, Thomas DY, Bergeron JJ (1991) SSR alpha and associated calnexin are major calcium binding proteins of the endoplasmic reticulum membrane. J Biol Chem 266:19599-19610.

Wadsworth G, Bhatt H, Hedgecock EM (1996) Neuroglia and pioneer neurons express UNC-6 to provide global and local netrin cues for guiding migrations in C. elegans. Neuron 16:34-46.

Wang H, Copeland NG, Gilbert DJ, Jenkins NA, Tessier-Lavigne M (1999) Netrin-3, a mouse homolog of human NTN2L, is highly expressed in sensory ganglia and shows differential binding to netrin receptors. J Neurosci 19:4938-4947.

Winberg ML, Mitchell KJ, Goodman CS (1998) Genetic analysis of the mechanisms controlling target selection: complementary and combinatorial functions of netrins, semaphorins, and IgCAMs. Cell 93:581-591.

Yin X, Peterson J, Gravel M, Braun P, Trapp BD (1997) CNP overexpression induces aberrant oligodendrocyte membranes and inhibits MBP accumulation and myelin compaction. J Neurosci Res 50:238-247.

Yin Y, Sanes JR, Miner JH (2000) Identification and expression of mouse netrin-4. Mech Dev 96:115-119. 